\title{
THE OCCURRENCE OF ANTIFIBRINOLYTIC PROPERTIES IN THE BLOOD OF PATIENTS WITH ACUTE HEMOLYTIC STREPTOCOCCUS INFECTIONS
}

\author{
By WILLIAM S. TILLETT \\ (From The Biological Division, Department of Medicine, The Johns Hopkins Medical School \\ and Hospital, Baltimore)
}

(Received for publication December 11, 1934)

The rapid dissolution of human fibrin clot by Streptococcus hemolyticus of the beta type is dependent upon the presence in cultures of an enzymic substance which is excreted by the organisms $(1,2)$. The bacterial product, which induces fibrinolysis, is characteristically elaborated by strains of hemolytic streptococci which cause acute infection in patients. Furthermore, the cultures, obtained from patients suffering with very severe types of illness, have been found to exhibit, with greatest frequency, the most potent fibrinolytic activity (3).

It has also been demonstrated that patients convalescent from acute infection due to hemolytic streptococci often develop a humoral property which is effectively antagonistic to the fibrin dissolving action of cultures of the infecting organisms (4).

Since the fibrinolytic product of streptococci has the properties of an enzyme, the inhibiting action of blood from convalescent individuals manifests itself as a specifically increased antienzymic effect. A review of the literature indicates that attempts to develop antiferments as an immunological process associated with antibody production have given variable results. Consequently it is not possible, at the present time, to state whether the acquired antifibrinolytic properties of patient's blood is dependent upon a specific antibody comparable to other antibacterial immunological processes, or is antienzymic through a special mechanism. Studies are now in progress which are directed toward identifying the antifibrinolytic properties.

In pursuing studies on the occurrence of the antifibrinolytic property of the blood, a number of observations have been made with plasma from a series of cases, both larger in number and more diverse in type than those which comprised the former report. The results are presented in this communication.

The observations have been made for the purpose of obtaining information concerning (1) the frequency with which this special response fol- lows acute streptococcus infections, (2) the approximate time in the course of the illness at which it was demonstrable, and (3) the relation of the presence or absence of humoral antifibrinolytic activity to the clinical course of the diseases, with respect to either complete recovery, or persistent suppurative complications, or fatal termination.

The patients, who were selected for the study, consisted of forty-five individuals representing different types of acute streptococcus diseases of varying degrees of severity. In some of the cases recovery was prompt and complete; in others, the illness was more severe and was characterized by metastasizing suppurative complications; another group consisted of individuals who died with fatal septicemia. The observations have been further extended to include results obtained with the blood of a few patients with rheumatic fever and acute hemorrhagic nephritis. The list of cases is as follows:

$$
\begin{aligned}
& 16 \text { cases of erysipelas } \\
& 5 \text { “" scarlet fever } \\
& 9 \text { " " acute tonsillitis } \\
& 3 \text { “ “ “ peritonsillar abscess } \\
& \text { "tions, } 10 \text { of which had septicemia } \\
& 8 \text { " " rheumatic fever } \\
& 5 \text { “ " acute hemorrhagic nephritis. }
\end{aligned}
$$

The observations were made with samples of blood obtained at repeated intervals during the course of the illness, both before and after recovery. Whenever it was possible, blood was procured at times when changes in the clinical course of the disease occurred, as represented by definite improvement, or the appearance of additional spread of the infection, or an increasing terminal septicemia.

The technical procedures, by which the dissolving action of streptococci on human fibrin is demonstrable, have been previously described in 
TABLE I

Cases of erysipelas

\begin{tabular}{|c|c|c|c|c|c|c|}
\hline \multirow{2}{*}{$\begin{array}{c}\text { Case } \\
\text { number }\end{array}$} & \multirow{2}{*}{$\begin{array}{c}\text { Patient. } \\
\text { History number. } \\
\text { Date of admission }\end{array}$} & \multirow{2}{*}{$\begin{array}{l}\text { Sex and } \\
\text { age }\end{array}$} & \multirow{2}{*}{$\begin{array}{l}\text { Day of disease } \\
\text { on admission }\end{array}$} & \multirow{2}{*}{$\begin{array}{l}\text { Approximate day } \\
\text { of recovery }\end{array}$} & \multicolumn{2}{|c|}{ Fibrinolytic test } \\
\hline & & & & & $\begin{array}{c}\text { Day of disease } \\
\text { (bleeding) }\end{array}$ & Result \\
\hline 1 & $\begin{array}{l}\text { Tin. } \\
19028 \\
\text { March 1, } 1934\end{array}$ & $\begin{array}{c}\text { years } \\
\mathrm{M} \\
48\end{array}$ & $3 d$ & 12 th & $\begin{array}{l}3 d \\
10 t h \\
22 d\end{array}$ & $\begin{array}{l}+ \\
++\end{array}$ \\
\hline 2 & $\begin{array}{l}\text { Che. } \\
21873 \\
\text { April 22, } 1934\end{array}$ & Fi & $3 d$ & 6 th & $\begin{array}{c}\text { 3d } \\
8 \text { th } \\
15 \text { th }\end{array}$ & + \\
\hline 3 & $\begin{array}{l}\text { Mye. } \\
40590 \\
\text { May 9, } 1934\end{array}$ & $\begin{array}{l}\text { M. } \\
25\end{array}$ & 6th & 11 th & $\begin{array}{r}6 \text { th } \\
9 \text { th } \\
14 \text { th }\end{array}$ & $\stackrel{\bar{t}}{++t}$ \\
\hline 5 & $\begin{array}{l}\text { Hop. } \\
52913 \\
\text { December 27, } 1933\end{array}$ & $\begin{array}{l}\text { M. } \\
38\end{array}$ & 6 th & $8-10$ th & $\begin{array}{r}6 \mathrm{th} \\
14 \mathrm{th}\end{array}$ & $\begin{array}{l}++t \\
+++t\end{array}$ \\
\hline 6 & $\begin{array}{l}\text { Fis. } \\
52966 \\
\text { December 30, } 1933\end{array}$ & $\begin{array}{l}\text { M. } \\
13\end{array}$ & 9 th & 9 th & $\begin{array}{l}9 \text { th } \\
16 \text { th }\end{array}$ & $\begin{array}{l}+++ \\
++++\end{array}$ \\
\hline 7 & $\begin{array}{l}\text { Dob. } \\
863 \\
\text { November } 30,1933\end{array}$ & $\begin{array}{l}\mathrm{F} . \\
26\end{array}$ & 10 th & 17 th & $\begin{array}{l}\text { 10th } \\
18 \text { th } \\
26 \text { th }\end{array}$ & $\begin{array}{c}+ \\
+\frac{1}{-}\end{array}$ \\
\hline 8 & $\begin{array}{l}\text { Ber. } \\
54474 \\
\text { March 25, } 1934\end{array}$ & F. & $2 d$ & 5 th & $\begin{array}{l}2 \mathrm{~d} \\
6 \mathrm{th} \\
11 \mathrm{th} \\
14 \mathrm{th}\end{array}$ & $\begin{array}{l}- \\
- \\
-\end{array}$ \\
\hline 11 & $\begin{array}{l}\text { Kar. } \\
53577 \\
\text { February 1, } 1934\end{array}$ & $\begin{array}{l}\mathrm{F} . \\
38\end{array}$ & 4 th & $7 \mathrm{th}$ & $\begin{array}{r}4 \text { th } \\
7 \text { th } \\
12 \text { th }\end{array}$ & $\begin{array}{c}+ \\
++ \\
+t\end{array}$ \\
\hline 12 & $\begin{array}{l}\text { Bri. } \\
53162 \\
\text { January 10, } 1934\end{array}$ & M. & 4 th & 4 th & $\begin{array}{r}5 \text { th } \\
13 \text { th }\end{array}$ & $\begin{array}{c}++t \\
-\end{array}$ \\
\hline 13 & $\begin{array}{l}\text { Gra. } \\
54472 \\
\text { March 25, } 1934\end{array}$ & F. & 4 th & 9 th & $\begin{array}{r}4 \text { th } \\
10 \text { th }\end{array}$ & $\stackrel{+t}{+t+t}$ \\
\hline 14 & $\begin{array}{l}\text { Cla. } \\
53856 \\
\text { February 18, } 1934\end{array}$ & $\begin{array}{l}\text { M. } \\
68\end{array}$ & 4 th & 9th & $\begin{array}{r}6 \mathrm{th} \\
12 \mathrm{th}\end{array}$ & $\stackrel{++}{t+t}$ \\
\hline 15 & $\begin{array}{l}\text { Cun. } \\
54007 \\
\text { February 28, } 1934\end{array}$ & $\begin{array}{l}\mathrm{F} . \\
45\end{array}$ & $3 d$ & 5 th-7th & $\begin{array}{l}3 \mathrm{~d} \\
12 \mathrm{th} \\
18 \mathrm{th} \\
\end{array}$ & $\begin{array}{c}++ \\
+ \\
+\end{array}$ \\
\hline 16 & $\begin{array}{l}\text { Hor. } \\
53792 \\
\text { February 14, } 1934\end{array}$ & $\begin{array}{l}\mathrm{F} . \\
56\end{array}$ & 6 th & $23 d$ & $\begin{array}{l}\text { 6th } \\
16 \text { th } \\
18 \text { th } \\
22 \mathrm{~d} \\
24 \mathrm{th} \\
35 \mathrm{th}\end{array}$ & $\begin{array}{l}\overline{-} \\
\bar{z} \\
\overline{-}\end{array}$ \\
\hline
\end{tabular}


detail (1). Briefly summarized, a test consists in mixing plasma from the patient's blood with a highly fibrinolytic living broth culture of streptococci. Coagulation of the plasma-culture mixture is induced by the addition of $\mathrm{CaCl}_{2}$. The tubes are then placed in the water bath at $37.5^{\circ} \mathrm{C}$. and the time between clot formation and dissolution is noted. The activity of the test culture (Strain Co) was always established by the use of plasma clot from the blood of a normal individual. The cultures, which were utilized in testing the patient's blood, always dissolved the coagulum of normal blood in less than fifteen minutes.

A measure of the resistance to lysis, which may occur with the fibrin clot of a patient's plasma, has been obtained by determining the time required for liquefaction. Since the interval varied with the blood of different patients, the degrees of resistance have been graded in the following manner.

$$
\begin{aligned}
& ++++ \text { indicates no dissolution in } 24 \text { hours. } \\
& +++ \text { " dissolution in } 8 \text { to } 24 \text { hours. } \\
& ++ \text { " " " } 3 \text { to } 8 \text { hours. } \\
& + \text { " " " } 1 \text { to } 3 \text { hours. } \\
& \text { - " " "less than } 1 \text { hour. }
\end{aligned}
$$

The above schema is used in the Tables of this article.

\section{Cases of erysipelas}

The data concerning these sixteen cases are recorded in Table I. All of these patients recovered.

Thirteen ( 81 per cent) of the sixteen patients with erysipelas either developed resistance to the streptococcal fibrinolysin during the period of observation or exhibited a high degree of insusceptibility at the time of obtaining the first sample of blood.

One patient, Number 15 , possessed a moderate degree of resistance on the third day of disease, but it decreased during convalescence. This patient was treated with anti-erysipelas serum.

Two patients, Numbers 8 and 16, developed no demonstrable antifibrinolytic response during the stay in the hospital. It is interesting to note that one of these patients (Number 16) had a second attack of erysipelas immediately following the first. Ultimate recovery was, however, complete, even though the usual response was not detected. The illness in the other patient (Number 8), who failed to develop an appreciable resistance to lysis, was not unusually prolonged. Her recovery was complete and uneventful.

From an analysis of the results in Table I with respect to the time of the appearance of antifibrinolytic resistance in relation to the course of the disease, it can be noted that twelve of the sixteen patients possessed the property (rated ++ or stronger) at or about the time of recovery. This relationship was approximated regardless of the duration of the illness, the two extremes of which are exemplified by Patient Number 12 who recovered on the fourth day and had an antifibrinolytic titer of ++++ on the fifth day, and by Patient Number 7 who recovered on the seventeenth day and had an artifibrinolytic titer of +++ on the eighteenth day.

In spite of the frequency with which antifibrinolytic resistance closely attends recovery, its appearance in erysipelas is occasionally delayed until convalescence is advanced. An example of this can be noted in the course of events in $\mathrm{Pa}$ tient Number 10 who began to improve on the eleventh day but his blood possessed no antilytic property until the twenty-first day.

\section{Cases of scarlet fever, acute tonsillitis, and peri- tonsillar abscess}

Each of the seventeen cases, included in this group, had an illness characterized by acute onset, relatively short febrile course, and uneventful recovery. The results are presented in Table II. Hemolytic streptococci of the beta type were the predominant organisms present in throat cultures from each of the patients.

Eleven ( 64 per cent) of the seventeen patients either developed antifibrinolytic properties during the stay in the hospital or possessed the specific resistance to a high degree at the time of obtaining the first sample of blood. Blood from the remaining six, however, did not inhibit lysis even though tests were made with specimens obtained late in convalescence.

The frequency with which patients having acute upper respiratory infections developed antilytic resistance was less ( 64 per cent) than that found with the erysipelatous group ( 81 per cent). A second difference between these two groups was noted by the fact that antilytic properties were usually not demonstrable in the blood of patients with acute infections of the throat (for example, 
TABLE II

Cases of scarlet fever, acute tonsillitis, and peritonsillar abscess

\begin{tabular}{|c|c|c|c|c|c|c|}
\hline \multirow{2}{*}{$\begin{array}{l}\text { Case } \\
\text { num- } \\
\text { ber }\end{array}$} & \multirow{2}{*}{$\begin{array}{l}\text { Patient. } \\
\text { History number. } \\
\text { Date of admission }\end{array}$} & \multirow{2}{*}{$\begin{array}{l}\text { Sex and } \\
\text { age }\end{array}$} & \multirow{2}{*}{ Disease } & \multirow{2}{*}{$\begin{array}{c}\text { Approximate } \\
\text { day of } \\
\text { recovery }\end{array}$} & \multicolumn{2}{|c|}{ Fibrinolytic test } \\
\hline & & & & & $\underset{\text { Day of disease }}{\text { (bleeding) }}$ & Result \\
\hline 1 & $\begin{array}{l}\text { Rav. } \\
52175 \\
\text { November } 8,1933\end{array}$ & $\begin{array}{l}\text { years } \\
\mathrm{F} . \\
23\end{array}$ & Scarlet fever & 9th & $\begin{array}{r}2 \mathrm{~d} \\
9 \mathrm{th} \\
14 \mathrm{th} \\
21 \mathrm{st}\end{array}$ & $\begin{array}{c}- \\
++ \\
+++\end{array}$ \\
\hline 2 & $\begin{array}{l}\text { Den. } \\
\text { Not hospitalized } \\
\text { Case }\end{array}$ & $\begin{array}{l}\mathrm{M} . \\
12\end{array}$ & Scarlet fever & 5 th & $\begin{array}{l}5 \text { th } \\
15 \text { th } \\
21 \text { st }\end{array}$ & $\begin{array}{c}\overline{+} \\
+++\end{array}$ \\
\hline 3 & $\begin{array}{l}\text { Owi. } \\
52432 \\
\text { November 23, } 1933\end{array}$ & $F_{j}$ & Scarlet fever & 5 th-8th & $\begin{array}{l}\text { 6th } \\
33 \mathrm{~d}\end{array}$ & $\begin{array}{c}++++ \\
+\end{array}$ \\
\hline 4 & $\begin{array}{l}\text { Jon. } \\
51844 \\
\text { October 19, } 1933\end{array}$ & F. & Scarlet fever & 7 th & $\begin{array}{r}\text { th } \\
14 \text { th } \\
21 \text { st } \\
27 \text { th }\end{array}$ & $\begin{array}{l}- \\
- \\
-\end{array}$ \\
\hline 5 & $\begin{array}{l}\text { Kea. } \\
53804 \\
\text { February 15, } 1934\end{array}$ & $\mathrm{M}$. & Scarlet fever & 9 th-12th & $\begin{array}{c}3 \mathrm{~d} \\
14 \mathrm{th} \\
24 \mathrm{th} \\
44 \mathrm{th}\end{array}$ & $\begin{array}{l}\bar{z} \\
\overline{-}\end{array}$ \\
\hline 6 & $\begin{array}{l}\text { Sco. } \\
52522 \\
\text { November } 30,1933\end{array}$ & M. & Peritonsillar abscess & 10th-13th? & \begin{tabular}{|l}
$3 \mathrm{~d}$ \\
$8 \mathrm{th}$ \\
$12 \mathrm{th}$
\end{tabular} & $\begin{array}{c}\overline{+} \\
+++\end{array}$ \\
\hline 7 & $\begin{array}{l}\text { Shi. } \\
52293 \\
\text { November 15, } 1933\end{array}$ & $\begin{array}{l}\text { M. } \\
20\end{array}$ & Peritonsillar abscess & 13th & $\begin{array}{l}\text { 6th } \\
15 \text { th } \\
24 \text { th }\end{array}$ & $\begin{array}{c}++ \\
+ \\
+\end{array}$ \\
\hline 8 & $\begin{array}{l}\text { Sha. } \\
55051 \\
\text { April 23, } 1934\end{array}$ & $\begin{array}{l}\text { M. } \\
27\end{array}$ & Peritonsillar abscess & 12 th & $\begin{array}{l}\text { 6th } \\
\text { 15th } \\
33 d\end{array}$ & $\bar{z}$ \\
\hline 9 & $\begin{array}{l}\text { Mer. } \\
52433 \\
\text { November 23, } 1933\end{array}$ & $\begin{array}{l}\text { F. } \\
22\end{array}$ & Acute tonsillitis & 6th & $\begin{array}{c}3 \mathrm{dd} \\
10 \text { th } \\
20 \text { th }\end{array}$ & $\frac{+}{+}++$ \\
\hline 10 & $\begin{array}{l}\text { Lan. } \\
54312 \\
\text { March 18, } 1934 \\
\end{array}$ & $\begin{array}{l}F \\
23\end{array}$ & Acute tonsillitis & 6th & $\begin{array}{r}4 \text { th } \\
9 \text { th } \\
24 \text { th } \\
\end{array}$ & $\begin{array}{c}+ \\
+ \\
+++\end{array}$ \\
\hline 11 & $\begin{array}{l}\text { Hec. } \\
52886 \\
\text { December } 26,1933\end{array}$ & $\begin{array}{l}\text { M. } \\
26\end{array}$ & Acute tonsillitis & 7 th & $\begin{array}{r}\text { 4th } \\
12 \text { th }\end{array}$ & $\begin{array}{c}+++ \\
++++\end{array}$ \\
\hline 12 & $\begin{array}{l}\text { Gei. } \\
2768 \\
\text { December 12, } 1933\end{array}$ & $\begin{array}{l}\text { M. } \\
30\end{array}$ & Acute tonsillitis & $3 d$ & $\begin{array}{c}3 \mathrm{~d} \\
8 \mathrm{th} \\
23 \mathrm{~d}\end{array}$ & $\begin{array}{c}\overline{-} \\
+\overline{+}+\end{array}$ \\
\hline 13 & $\begin{array}{l}\text { Hen. } \\
54587 \\
\text { March 31, } 1934\end{array}$ & $\begin{array}{l}F . \\
28\end{array}$ & Acute tonsillitis & 10th & $\begin{array}{l}\text { 4th } \\
10 \text { th } \\
21 \text { st }\end{array}$ & $\begin{array}{c}\bar{z} \\
++++\end{array}$ \\
\hline 14 & $\begin{array}{l}\text { Ber. } \\
8458 \\
\text { October 23, } 1933\end{array}$ & $\begin{array}{l}\text { F. } \\
34\end{array}$ & Acute tonsillitis & 5 th & $\begin{array}{r}3 d \\
8 \text { th } \\
18 \text { th } \\
\end{array}$ & $\begin{array}{c}+ \\
++ \\
+++\end{array}$ \\
\hline 15 & $\begin{array}{l}\text { Vol. } \\
53252 \\
\text { January } 15,1934\end{array}$ & $\begin{array}{l}\mathrm{M} \\
32\end{array}$ & Acute tonsillitis & 4 th & $\begin{array}{c}3 \mathrm{~d} \\
27 \mathrm{th}\end{array}$ & $\bar{t}$ \\
\hline 16 & $\begin{array}{l}\text { Bla. } \\
51994 \\
\text { October 30, } 1933\end{array}$ & $\begin{array}{l}\text { M. } \\
22\end{array}$ & Acute tonsillitis & 5 th & $\begin{array}{r}\text { 3d } \\
9 \text { th } \\
18 \text { th } \\
30 \text { th } \\
\end{array}$ & $\begin{array}{l}- \\
\overline{-} \\
-\end{array}$ \\
\hline 17 & $\begin{array}{l}\text { Gar. } \\
\text { Not hospitalized } \\
\text { Case }\end{array}$ & $\begin{array}{l}\text { M. } \\
28\end{array}$ & Acute tonsillitis & 5 th & $\begin{array}{l}5 \text { th } \\
18 \text { th } \\
27 \text { th } \\
36 \text { th } \\
45 \text { th }\end{array}$ & $\begin{array}{l}\bar{z} \\
\bar{z} \\
\bar{z}\end{array}$ \\
\hline
\end{tabular}


Number 1 and Number 12) promptly at the time of recovery but appeared from the second to fourth week in convalescence. The delayed response, often encountered in patients with acute streptococcus infections of the throat, was noted in the former report (4) and seems to be characteristic of the upper respiratory type of infection.

\section{Cases of severe, progressive suppurative infec- tions, and septicemias}

In contrast to the patients just described, in whom the illness was brief and recovery occurred early and was complete, the cases, twelve in number, which will now be presented, had severe infections. Seven of them died. Ten had septicemia.

In Table III the results of tests with the plasma clot from the patients are given together with brief notation of relevant clinical data.

From Table III it can be seen that the blood from only three ( 25 per cent) of the twelve patients in this group was capable of significantly retarding the fibrinolytic bacterial activity. It is also noteworthy that all three of the patients who developed antifibrinolytic properties, recovered. Two of the three had septicemia and the antilytic response was demonstrable in the period of time during which the general infection disappeared. The observations were not made, however, with sufficient frequency to determine the exact time relationship between the cessation of septicemia and the appearance of the antifibrinolytic effect.

Of the remaining nine patients, none possessed humoral, antifibrinolytic properties. Seven of them died of the streptococcus infection. Some of the fatal cases died very soon after the beginning of the infection and so may have succumbed before the response could be elicited.

The two patients (Numbers 1 and 2), who recovered, but in whose blood antifibrinolytic properties were not detectable, were of special interest. They were followed through long severe illnesses and also during convalescence. In no test with the blood of either patient did the rate of clot dissolution differ from that of normal blood. It is of interest to note, however, that the reactivation of the infection occurred in the third to fourth week after the beginning of the first signs of the illness. In the course of the self limiting acute streptococcus infections of the upper respiratory tract (Table II) it has just been noted that this late period was found to be the time at which antifibrinolytic resistance frequently appeared. The possibility is suggested, therefore, that the liability to exacerbation or continuation of infection is greater among patients without antilytic resistance than in those who develop the capacity to inhibit fibrinolytic activity.

When the data presented in this article are analyzed with respect to the activity of the infection in relation to the presence or absence of antifibrinolytic properties in the blood, the following results are obtained:

Of thirteen patients, who did not possess antilytic properties within three weeks after the first manifestations of infection (Patients Numbers 8 and 16 in Table I, Numbers $4,5,8,15,16$, and 17 in Table II, and Numbers 1, 2, 3, 6, and 9 in Table III), two died (Numbers 6 and 9 in Table III) and four had recrudescences and prolongation of the illness (Number 16 in Table I, and Numbers 1, 2, and 3 in Table III). In contrast to this result, none of the twenty-eight patients, who developed resistance to streptococcal lysis, showed any evidence of continued bacterial invasion after the specific response was established.

\section{Cases of acute rheumatic fever and acute hemor- rhagic nephritis}

Of the thirteen patients, who comprise this group, each had signs and laboratory findings indicating active rheumatic state or renal involvement. In addition, each case either gave the usual history of some local infection preceding the visceral affection or presented, at the time of admission, evidence of such an infection. The site of the activating infection is given in Table IV. From four of the eight rheumatic patients and from each of the nephritic cases, hemolytic streptococci of the beta type were recovered. Since repeated throat cultures were not made on the four rheumatic patients who were negative for hemolytic streptococci on one or two occasions, the bacteriological findings may be inconclusive.

The clinical course of the patients outlined in Table IV, is given with respect to day of disease from the standpoint of the local acute infection, and not on the basis of the rheumatic fever or 
TABLE III

Cases of septicemia and severe suppurative infections

\begin{tabular}{|c|c|c|c|c|c|c|c|c|}
\hline $\begin{array}{c}\text { Case } \\
\text { num- } \\
\text { ber }\end{array}$ & $\begin{array}{l}\text { Patient. } \\
\text { History number. } \\
\text { Date of admission }\end{array}$ & $\begin{array}{c}\text { Sex and } \\
\text { age }\end{array}$ & Initial infection & Complications & Final outcome & $\begin{array}{l}\text { Day of } \\
\text { disease }\end{array}$ & $\begin{array}{c}\text { Blood } \\
\text { culture* }\end{array}$ & $\begin{array}{c}\text { Fibrinolytic } \\
\text { test }\end{array}$ \\
\hline 1 & $\begin{array}{l}\text { Sta. } \\
51946 \\
\text { October 27, } 1933\end{array}$ & $\begin{array}{c}\text { years } \\
\text { F. } \\
5\end{array}$ & $\begin{array}{l}\text { Scarlet fever } 4 \\
\text { weeks ago }\end{array}$ & $\begin{array}{l}\text { Otitis media, } \\
\text { mastoiditis, sinus } \\
\text { thrombosis, mul- } \\
\text { tiple abscesses }\end{array}$ & $\begin{array}{l}\text { Recovered. } \\
\text { Temperature } \\
\text { normal about } \\
\text { 85th day }\end{array}$ & $\begin{array}{r}25 \mathrm{th} \\
45 \mathrm{th} \\
55 \mathrm{th} \\
70 \mathrm{th} \\
80 \mathrm{th} \\
90 \mathrm{th} \\
115 \mathrm{th}\end{array}$ & $\begin{array}{l}\overline{80} \\
+ \\
380 \\
+ \\
-\end{array}$ & $\begin{array}{l}- \\
- \\
- \\
- \\
-\end{array}$ \\
\hline 2 & $\begin{array}{l}\text { Hos. } \\
54874 \\
\text { April 14, } 1934\end{array}$ & $\begin{array}{l}\mathrm{M} . \\
12\end{array}$ & $\begin{array}{l}\text { Otitis media } 18 \\
\text { days ago }\end{array}$ & $\begin{array}{l}\text { Mastoiditis, si- } \\
\text { nus thrombosis, } \\
\text { osteomyelitis }\end{array}$ & $\begin{array}{l}\text { Recovered. } \\
\text { Temperature } \\
\text { normal about } \\
45 \text { th day }\end{array}$ & $\begin{array}{l}20 \text { th } \\
25 \text { th } \\
30 \text { th } \\
45 \text { th } \\
65 \text { th }\end{array}$ & $\frac{3}{-}$ & $\begin{array}{l}- \\
- \\
- \\
-\end{array}$ \\
\hline 3 & $\begin{array}{l}\text { Wal. } \\
81278 \\
\text { December 8, } 1933\end{array}$ & 10 mos. & $\begin{array}{l}\text { Upper respira- } \\
\text { tory infection } 7 \\
\text { days ago }\end{array}$ & $\begin{array}{l}\text { Adenitis, osteo- } \\
\text { myelitis, mul- } \\
\text { tiple abscesses }\end{array}$ & $\begin{array}{l}\text { Recovered. } \\
\text { Temperature } \\
\text { normal about } \\
\text { 50th day }\end{array}$ & $\begin{array}{r}15 \mathrm{th} \\
25 \mathrm{th} \\
45 \mathrm{th} \\
65 \mathrm{th} \\
120 \mathrm{th}\end{array}$ & $\begin{array}{c}500+ \\
70 \\
-\end{array}$ & 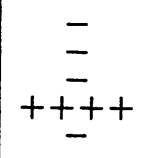 \\
\hline 4 & $\begin{array}{l}\text { Woo. } \\
51424 \\
\text { March 23, } 1934\end{array}$ & F. & $\begin{array}{l}\text { Otitis media } 6 \\
\text { days ago }\end{array}$ & $\begin{array}{l}\text { Erysipelas, } \\
\text { mastoiditis }\end{array}$ & $\begin{array}{l}\text { Recovered. } \\
\text { Temperature } \\
\text { normal about } \\
17 \text { th day }\end{array}$ & $\begin{array}{l}10 \text { th } \\
15 \text { th } \\
20 \text { th } \\
30 \text { th }\end{array}$ & \pm & $\begin{array}{c}\bar{t} \\
+++t \\
++t+\end{array}$ \\
\hline 5 & $\begin{array}{l}\text { For. } \\
53143 \\
\text { January 9, } 1934\end{array}$ & $\begin{array}{l}\mathrm{F} \\
25\end{array}$ & $\begin{array}{l}\text { Acute tonsillitis } \\
2 \text { weeks ago }\end{array}$ & $\begin{array}{l}\text { Pneumonia } \\
\text { (pneumococcus } \\
\text { Group IV), } \\
\text { empyema (hemo- } \\
\text { lytic streptocci) }\end{array}$ & $\begin{array}{l}\text { Recovered. } \\
\text { Acute process } \\
\text { subsided about } \\
20 \text { th day }\end{array}$ & $\begin{array}{l}15 \text { th } \\
25 \text { th } \\
40 \text { th } \\
120 \text { th }\end{array}$ & - & $\begin{array}{c}+ \\
++++ \\
+++ \\
+++\end{array}$ \\
\hline 6 & $\begin{array}{l}\text { Bea. } \\
54716 \\
\text { April 6, } 1934\end{array}$ & M. & $\begin{array}{l}\text { Otitis media } 10 \\
\text { weeks ago }\end{array}$ & $\begin{array}{l}\text { Mastoiditis, } \\
\text { brain abscess }\end{array}$ & Died 90th day & $\begin{array}{l}75 \text { th } \\
85 \text { th }\end{array}$ & - & $\bar{t}$ \\
\hline 7 & $\begin{array}{l}\text { Coy. } \\
29871 \\
\text { December 18, } 1933\end{array}$ & Fi & $\begin{array}{l}\text { Cervical adenitis } \\
5 \text { days ago }\end{array}$ & Abscess of neck & Died 9th day & $\begin{array}{l}6 \text { th } \\
8 \text { th }\end{array}$ & $\begin{array}{r}2 \\
15\end{array}$ & - \\
\hline 8 & $\begin{array}{l}\text { Wil. } \\
54087 \\
\text { March 1, } 1934\end{array}$ & F. & $\begin{array}{l}\text { Abortion } 2 \text { days } \\
\text { ago }\end{array}$ & Puerperal sepsis & Died 15th day & $\begin{array}{r}5 \text { th } \\
14 \text { th }\end{array}$ & $\stackrel{+}{+}$ & $\overline{-}$ \\
\hline 9 & $\begin{array}{l}\text { Fle. } \\
21184 \\
\text { March 30, } 1934\end{array}$ & $\begin{array}{l}\mathrm{F} \\
2 \mathbf{3}\end{array}$ & $\begin{array}{l}\text { Postpartum } 6 \\
\text { days }\end{array}$ & Puerperal sepsis & Died 27th day & $\begin{array}{l}9 \text { th } \\
18 \text { th } \\
25 \text { th }\end{array}$ & $\begin{array}{l}40 \\
+ \\
+\end{array}$ & $\overline{-}$ \\
\hline 10 & $\begin{array}{l}\text { Mol. } \\
52816 \\
\text { December 20, 1933 }\end{array}$ & $\begin{array}{l}\mathrm{F} \text {. } \\
20\end{array}$ & $\begin{array}{l}\text { Acute tonsillitis } \\
4 \text { days ago }\end{array}$ & Peritonitis & Died 8th day & 5 th & 2 & - \\
\hline 11 & $\begin{array}{l}\text { Nea. } \\
53549 \\
\text { February 9, } 1934\end{array}$ & Fi & Postoperative & Wound infection & Died 7th day & 4th & + & - \\
\hline 12 & $\begin{array}{l}\text { Bai. } \\
\text { 53830 } \\
\text { March 5, } 1934\end{array}$ & F. & Postoperative & Wound infection & Died 7th day & $\begin{array}{l}3 \mathrm{~d} \\
6 \mathrm{th}\end{array}$ & $\begin{array}{r}105 \\
1000\end{array}$ & - \\
\hline
\end{tabular}

* Numerals indicate number of colonies of hemolytic streptococci per cc. of blood.

+ sign indicates positive culture not measured quantitatively.

- sign indicates negative culture. 
TABLE IV

Cases of active rheumatic fever and acute hemorrhagic nephritis

\begin{tabular}{|c|c|c|c|c|c|c|c|c|c|}
\hline \multirow{2}{*}{$\begin{array}{c}\text { Case } \\
\text { num- } \\
\text { ber }\end{array}$} & \multirow{2}{*}{$\begin{array}{l}\text { Patient. } \\
\text { History number. } \\
\text { Date of admission }\end{array}$} & \multirow[b]{2}{*}{$\begin{array}{c}\text { Sex and } \\
\text { age }\end{array}$} & \multirow[b]{2}{*}{ Rheumatic fever } & \multicolumn{3}{|c|}{ Local infection } & \multicolumn{2}{|c|}{ Fibrinolytic test } & \multirow{2}{*}{$\begin{array}{l}\text { Rheumatic state } \\
\text { at time of } \\
\text { last test }\end{array}$} \\
\hline & & & & Site & $\begin{array}{c}\text { Duration } \\
\text { of symp- } \\
\text { toms }\end{array}$ & Culture* & $\begin{array}{l}\text { Day of dis- } \\
\text { ease (local } \\
\text { infection) }\end{array}$ & Result & \\
\hline 1 & $\begin{array}{l}\text { Lew. } \\
30093 \\
\text { November 23, } 1933\end{array}$ & $\begin{array}{l}\text { years } \\
\text { F. } \\
17\end{array}$ & $\begin{array}{l}\text { Recurrent for } 12 \\
\text { years }\end{array}$ & Throat & 5 days & Positive & $\begin{array}{l}6 \text { th } \\
18 \text { th } \\
30 \text { th }\end{array}$ & + & $\begin{array}{l}\text { Improved, not } \\
\text { quiescent }\end{array}$ \\
\hline 2 & $\begin{array}{l}\text { Gil. } \\
52627 \\
\text { December 6, } 1933\end{array}$ & $\begin{array}{l}\text { M. } \\
16\end{array}$ & $\begin{array}{l}\text { First acute symp- } \\
\text { toms } 3 \text { weeks ago }\end{array}$ & Throat & 3 weeks & $\begin{array}{l}2 \text { cul- } \\
\text { tures } \\
\text { negative }\end{array}$ & $\begin{array}{l}21 \text { st } \\
\text { 30th } \\
\text { 45th } \\
55 \text { th }\end{array}$ & & Quiescent \\
\hline 3 & $\begin{array}{l}\text { Cor. } \\
54357 \\
\text { March 19, } 1934\end{array}$ & M. & $\begin{array}{l}\text { First acute symp- } \\
\text { toms } 1 \text { month ago }\end{array}$ & Throat & 3 weeks & $\begin{array}{l}1 \text { cul- } \\
\text { ture } \\
\text { negative }\end{array}$ & $\begin{array}{l}27 \mathrm{th} \\
55 \mathrm{th}\end{array}$ & & $\begin{array}{l}\text { Improved, not } \\
\text { quiescent }\end{array}$ \\
\hline 4 & $\begin{array}{l}\text { Dec. } \\
23642 \\
\text { November 7, } 1933\end{array}$ & $\begin{array}{l}\text { M. } \\
32\end{array}$ & $\begin{array}{l}\text { Recurrent for } 7 \\
\text { years }\end{array}$ & $\begin{array}{l}\text { Upper } \\
\text { respira- } \\
\text { torytract }\end{array}$ & $\begin{array}{l}1 \\
\text { month } \\
\text { (mild) }\end{array}$ & Positive & $\begin{array}{l}\text { 21st } \\
\text { 35th }\end{array}$ & & $\begin{array}{l}\text { Improved, not } \\
\text { quiescent }\end{array}$ \\
\hline 5 & $\begin{array}{l}\text { Col. } \\
35136 \\
\text { May 14, } 1934\end{array}$ & $\begin{array}{l}\text { F. } \\
16\end{array}$ & $\begin{array}{l}\text { Recurrent for } 3 \\
\text { years }\end{array}$ & Throat & 1 & Positive & $\begin{array}{l}\text { 35th } \\
55 \text { th }\end{array}$ & & Quiescent \\
\hline 6 & $\begin{array}{l}\text { Gro. } \\
52448\end{array}$ & F. & $\begin{array}{l}\text { Chorea } 5 \text { years } \\
\text { ago. Polyarthritis } \\
3 \text { weeks ago }\end{array}$ & $?$ & $?$ & $\begin{array}{l}1 \text { cul- } \\
\text { ture } \\
\text { negative }\end{array}$ & $\begin{array}{l}\text { 30th? } \\
55 \text { th? }\end{array}$ & + & Quiescent \\
\hline 7 & $\begin{array}{l}\text { Sch. } \\
55180 \\
\text { April 30, } 1934\end{array}$ & $\begin{array}{l}\text { F. } \\
14\end{array}$ & $\begin{array}{l}\text { Recurrent for } 6 \\
\text { years }\end{array}$ & Throat & 6 weeks & $\begin{array}{l}1 \text { cul- } \\
\text { ture } \\
\text { negative }\end{array}$ & $\begin{array}{r}40 \mathrm{th} \\
50 \mathrm{th} \\
120 \mathrm{th}\end{array}$ & & Unimproved \\
\hline \multirow[t]{2}{*}{8} & $\begin{array}{l}\text { Rol. } \\
55651 \\
\text { May 22, } 1934\end{array}$ & $\begin{array}{l}\mathrm{F} \\
14\end{array}$ & $\begin{array}{l}\text { First symptoms } 2 \\
\text { weeks ago }\end{array}$ & Throat & 3 weeks & Positive & $\begin{array}{l}30 \text { th } \\
55 \text { th } \\
85 \text { th }\end{array}$ & & Quiescent \\
\hline & & & Acute nephritis & & & & & & Acute nephritis \\
\hline 1 & $\begin{array}{l}\text { Yan. } \\
46383 \\
\text { January } 1,1934\end{array}$ & $\begin{array}{l}\text { F. } \\
19\end{array}$ & $\begin{array}{l}\text { First signs } 14 \\
\text { months ago 2nd } \\
\text { admission }\end{array}$ & Throat & 3 days & Positive & $\begin{array}{r}4 \text { th } \\
18 \text { th } \\
30 \text { th } \\
45 \text { th }\end{array}$ & + & Improved \\
\hline 2 & $\begin{array}{l}\text { Ger. } \\
52952 \\
\text { December 27, } 1933\end{array}$ & F. & $\begin{array}{l}\text { Edema appeared } \\
5 \text { days ago }\end{array}$ & Finger & 2 weeks & Positive & $\begin{array}{l}15 \text { th } \\
35 \text { th } \\
55 \text { th }\end{array}$ & $\begin{array}{l}+++t \\
++++ \\
+++t\end{array}$ & Improved \\
\hline 3 & $\begin{array}{l}\text { McK. } \\
\text { 53939 } \\
\text { March 18, } 1934\end{array}$ & $\underset{33}{M}$ & $\begin{array}{l}\text { Edema appeared } \\
5 \text { months ago }\end{array}$ & $\begin{array}{l}\text { Furun- } \\
\text { culosis } \\
\text { (recur- } \\
\text { rent) }\end{array}$ & $\begin{array}{l}9 \\
\text { months }\end{array}$ & Positive & $\begin{array}{l}\text { On } \\
\text { Adm. } \\
\text { 21st? } \\
\text { 35th? }\end{array}$ & $\begin{array}{l}-+ \\
+ \\
+\end{array}$ & $\begin{array}{l}\text { Slightly im- } \\
\text { proved }\end{array}$ \\
\hline 4 & $\begin{array}{l}\text { Pai. } \\
52292 \\
\text { November 15, 1933 }\end{array}$ & $\begin{array}{l}\text { F. } \\
45\end{array}$ & $\begin{array}{l}\text { Hematuria on ad- } \\
\text { mission }\end{array}$ & $\begin{array}{l}\text { Ery- } \\
\text { sipelas }\end{array}$ & 6 days & Positive & $\begin{array}{l}\text { 6th } \\
18 \text { th } \\
\text { 30th } \\
55 \text { th }\end{array}$ & $\begin{array}{l}\overline{+} \\
++ \\
-\end{array}$ & Improved \\
\hline 5 & $\begin{array}{l}\text { Sho. } \\
54066 \\
\text { March 4, } 1934\end{array}$ & $\underset{24}{M}$ & $\begin{array}{l}\text { Appeared after ad- } \\
\text { mission }\end{array}$ & $\begin{array}{l}\text { Periton- } \\
\text { sillar } \\
\text { abscess }\end{array}$ & 5 days & Positive & $\begin{array}{l}6 \text { th } \\
15 \text { th } \\
27 \text { th } \\
55 \text { th }\end{array}$ & $\begin{array}{l}\overline{-} \\
\overline{-}\end{array}$ & Improved \\
\hline
\end{tabular}

* Refers to presence or absence of hemolytic streptococcus of the beta type. 
nephritis. In a few instances, where the data are uncertain, the questionable factors are indicated.

Rheumatic fever. The results obtained with the eight cases of rheumatic fever (Table IV), demonstrate that resistance was present in the first specimen of blood or developed during the period of observation. The appearance of antifibrinolytic properties in patients with rheumatic fever seemed to follow the acute upper respiratory infection with about the same regularity as has been found in uncomplicated cases of acute tonsillitis, and was equally as definite in the patients from whom hemolytic streptococci were not recovered as in the others having positive cultures. Hadfield, Magee and Perry (5) have reported the results of observations on the antifibrinolytic resistance in a large number of patients with active or latent rheumatic fever. These investigators found that the plasma clot from cases of active disease was frequently resistant to lysis, whereas the fibrin from the blood of quiescent cases was susceptible. They further indicate that the determination of the presence or absence of the antifibrinolytic effect of the blood may be helpful in estimating the activity of the rheumatic state. The results obtained in this laboratory with a small group of patients confirm the findings of Hadfield and his associates.

Acute hemorrhagic nephritis. Each of the five cases of acute nephritis (Table IV) had a local infection from which hemolytic streptococci of the beta type were isolated. The plasma clot from four of the patients was definitely resistant. The fibrin from the blood of one patient (Sho.), who had peritonsillar abscess followed later by hematuria, was found to be susceptible in each of five tests performed at intervals for about seven weeks.

The presence of antifibrinolytic properties in the blood of patients with acute nephritis appears to follow the activating streptococcus infection in a manner comparable to the specific response evoked by acute diseases not complicated by renal involvement.

In summarizing all of the observations which are included in this article, the following results emerge :

Of thirty-eight patients who recovered from acute streptococcus infections, twenty-eight (73.6 per cent) either possessed at the time of admis- sion, or subsequently developed, a definite degree of antifibrinolytic resistance.

Of seven cases dying from infection by hemolytic streptococci, the fibrin clot from each was susceptible up to the time of death.

Of eight patients with acute rheumatic fever, the plasma clot from each was resistant during active infection.

Of five patients with acute hemorrhagic nephritis, four possessed antifibrinolytic resistance.

\section{DISCUSSION}

The frequency with which recovery from acute hemolytic streptococcus diseases is followed by the appearance in the circulating blood of a specific antisubstance directed against the fibrin dissolving action of streptococci, demonstrates the fact that the body takes cognizance of the fibrinolytic property of the infecting organism.

The results, which are presented in this report, concern the occurrence of the antifibrinolytic response in the blood of patients in relation to the course of the illnesses. For this purpose, cases were selected for study which presented different types of acute streptococcus infections of different degrees of severity. The diseases ranged from mild self limiting processes to more serious types of general infection or metastatic suppuration. The results demonstrate that most of the patients (73.6 per cent) who recovered possessed humoral antifibrinolytic properties. On the other hand, a few others overcame the infection without evoking an antilytic response. The development of antifibrinolysin, therefore, as measured in the circulating blood, although a common occurrence, was not found to be a universal sequel to acute streptococcus diseases. It is interesting to note, however, certain striking differences between the course of the diseases in the patients, who developed antifibrinolytic activity, and others, whose blood was devoid of this property. For example, antifibrinolysin was found in the blood of those individuals only whose recovery was complete and whose convalescence was not interrupted by additional reactivation of the streptococcus infection. On the other hand, antifibrinolysin was not detected in the blood of cases of fatal infection, and did not appear at the usual time (first to fourth week) in others with metastasizing suppurative processes. 
When, therefore, during the course of the illness, an examination of the blood revealed the presence of antifibrinolysin, the finding served as a reliable indication that the infection was progressively subsiding and that subsequent reinvasion by streptococci would not occur. On the other hand, the continued absence of antifibrinolytic properties was often suggestive of a liability to continuation or additional spread of the infection. This latter correlation was not, however, a constant finding, since some individuals recovered completely without the acquisition of antifibrinolysin.

Although the results which have been described are suggestive that the antifibrinolytic quality of the blood may, when present, aid in overcoming active streptococcus disease, its significance, if any, as part of the defense mechanism, is not clearly defined. It seems probable that the acquired power to inhibit the fibrinolytic action of the infecting organisms is a single element in the broad immune response which attends recovery.

From a consideration of the many investigations of hemolytic streptococci with respect to infection and resistance, it becomes increasingly evident that this single species of bacterium is possessed of several special properties, each of which may evoke a specific, and probably independent, immunological response. For example, agglutinins, opsonins, bacteriocidins, antitoxin, antistreptolysin, and antifibrinolysin have, under appropriate conditions, been demonstrated. That there may be other, as yet undefined, factors seems plausible.

Preliminary studies in this laboratory suggest that different individuals differ in the type of response as measured by variations in the production of the immune substances just mentioned. Investigations now in progress are directed, therefore, toward a consideration of the balance between the biological characteristics of the individual infecting strains and the capacity of the host to acquire the several forms of immunity. The results presented in this article are limited to a consideration of the response to a single function of pathogenic hemolytic streptococci.

\section{SUM MARY}

A specific antisubstance directed against the fibrin dissolving action of hemolytic streptococci was demonstrable in the blood of approximately seventy-five per cent of patients who recovered from acute streptococcus infections.

The fibrin clot from the blood of patients who died of the infection was, in no instance, capable of inhibiting the bacterial fibrinolytic action.

The antifibrinolytic response was demonstrable at the approximate time of recovery in some patients and, in others, was not detected until the second to fourth week in convalescence. Although there were exceptions, the specific response appeared during the course of erysipelas earlier than it did following acute streptococcus infections of the upper respiratory tract.

Twenty-eight patients developed antifibrinolytic resistance. All of them completely recovered and their convalescence was not interrupted by a reactivation of the streptococcus infection.

Seventeen patients failed to acquire humoral antifibrinolytic properties. In seven of those included in this group, the disease was self limiting and convalescence was uneventful. Of the remaining ten, seven died and three had prolonged illnesses due to exacerbations of active streptococcus infection.

In the few cases of active rheumatic fever and acute nephritis, which were studied, antifibrinolytic resistance was usually present. The response did not differ in its development from that which occurred in cases of acute streptococcus infection without the visceral affections of rheumatic fever or acute nephritis.

\section{BIBLIOGRAPHY}

1. Tillett, W. S., and Garner, R. L., The fibrinolytic activity of hemolytic streptococci. J. Exper. Med., 1933, 58, 485.

2. Garner, R. L., and Tillett, W. S., Biochemical studies on the fibrinolytic activity of hemolytic streptococci. I. Isolation and characterization of fibrinolysin. II. Nature of the reaction. J. Exper. Med., 1934, 60, 239 and 255.

3. Tillett, W. S., The fibrinolytic activity of hemolytic streptococci in relation to the source of strains and to cultural reactions. J. Bact. (In press.)

4. Tillett, W. S., Edwards, L. B., and Garner, R. L., Fibrinolytic activity of hemolytic streptococci. The development of resistance to fibrinolysis following acute hemolytic streptococcus infections. J. Clin. Invest., 1934, 13, 47.

5. Hadfield, G., Magee, V., and Perry, C. B., The lysis of fibrin by streptococci. Its application to the problems of rheumatic infection in children. Lancet, 1934, 226, 834. 